Revista de Comunicación y Salud, 2020, Vol. 10, oㅡ 2, pp. 265-286

Editado por Cátedra de Comunicación y Salud

ISSN: 2173-1675

\title{
LA COVID-19 EN LAS PORTADAS DE LOS DIARIOS DE DIFUSIÓN NACIONAL EN ESPAÑA
}

The COVID-19 on the front pages of national newspapers in Spain

\author{
María Monjas Eleta ${ }^{1}$ \\ Universidad de Valladolid. España. \\ mariamon@hmca.uva.es
}

Alejandro Rodríguez Holguín

Universidad de Valladolid. España

arodriguezholguin97@gmail.com

\author{
Alicia Gil-Torres \\ Universidad de Valladolid. España. \\ alicia.gil@uva.es
}

\section{Resumen}

Esta investigación analiza el tratamiento de la pandemia de COVID-19 en las portadas de los diarios $A B C$, El País, El Mundo, La Razón y La Vanguardia durante los meses de febrero, marzo y abril de 2020. El análisis permite comparar similitudes y diferencias a la vez que se observa la evolución en este período. Se recurre al análisis de contenido para determinar el espacio y la importancia del tema dentro de las portadas, así como los asuntos que se abordan, quiénes son los protagonistas en los titulares o fotografías y el léxico que emplean. El análisis se centra en la forma en que se comunican los acontecimientos acaecidos a la vez que se descubren las diferencias de criterio y estilo entre cabeceras de difusión nacional. Los resultados y conclusiones muestran que la información acerca de la COVID-19 gana protagonismo y ocupa más espacio en las portadas con el paso de las semanas y se incluyen gráficos e infografías a medida que la incidencia de la COVID-19 es mayor. También se puede apreciar tras el análisis de las portadas que los asuntos abordados por parte de los diarios varían con el tiempo, al igual que el vocabulario empleado es característico de cada medio.

Palabras clave: Pandemia; COVID-19; Coronavirus; España; Diarios; Portadas; Titulares.

1 Autora para correspondencia: María Monjas Eleta. mariamon@hmca.uva.es Profesora del Grado en Periodismo Universidad de Valladolid 
La COVID-19 en las portadas de los diarios de difusión nacional en España

\begin{abstract}
This research analyses the treatment of the COVID-19 pandemic on the front pages of the newspapers $A B C$, El País, El Mundo, La Razón and La Vanguardia during the months of February, March and April 2020. The analysis allows us to compare similarities and differences while observing the evolution in this period. Content analysis is used to determine the space and importance of the topic within the covers, as well as the issues being addressed, who the protagonists are in the headlines or photographs and the lexicon they use. The analysis focuses on how events are communicated while uncovering differences in approach and style between national headlines. The results and conclusions show that the information about COVID-19 gains prominence and takes up more space on the front pages as the weeks go by, and graphics and infographics are included as the incidence of COVID-19 increases. It can also be seen from the analysis of the covers that the issues addressed by the newspapers vary over time, as does the vocabulary used, which is characteristic of each medium
\end{abstract}

Keywords: Pandemic; COVID-19; Coronavirus; Spain; Newspapers; Front page; Headlines.

\title{
Cómo citar el artículo
}

Monjas Eleta, M., Rodríguez Holguín, A. y Gil-Torres, A. (2020). La COVID-19 en las portadas de los diarios de difusión nacional en España. Revista de Comunicación y Salud, 10 (2), 265-286. doi: https://doi.org/10.35669/rcys.2020.10(2).265-286

\section{INTRODUCCIÓN}

El origen de la COVID-19 se sitúa, según la Organización Mundial de la Salud (OMS), al día 31 de diciembre de 2019 en la localidad china de Wuhan. El 11 de marzo la OMS declara pandemia mundial la epidemia de COVID-19 debido a su incidencia global. Más de 118.000 casos en 114 países y 4291 personas fallecidas a causa de la COVID-19. En España, el 14 de marzo, el presidente del Gobierno, Pedro Sánchez, decreta el Estado de Alarma previsto en el artículo 116 de la Constitución que contempla la intervención del Ejecutivo para tomar medidas de restricción severas de la actividad cotidiana de los ciudadanos. En esta fecha, el virus ya había afectado a 5.753 personas, se contabilizaron 136 fallecidos y 293 ingresados en la $\mathrm{UCl}$ (Departamento de Seguridad Nacional, 2020). En las semanas siguientes se sucedieron seis prórrogas del Estado de Alarma, propuestas por el gobierno y aprobadas en el Congreso de los Diputados. A las 00:00 horas del 21 de junio, esta situación excepcional se daba por finalizada con unas medidas mucho más laxas, la denominada "nueva normalidad".

Este artículo aborda el tratamiento de esta crisis sanitaria a través de las portadas de los cinco principales diarios de tirada nacional entre los meses de febrero y abril. La portada es el espacio en el que el periódico muestra con mayor claridad la tarea de inclusión, exclusión y jerarquización de protagonistas y temas de la actualidad (Borrat, 2003, López Rabadán y Casero Ripollés, 2012). La portada de prensa compite y se

Revista de Comunicación y Salud, 2020, Vol. 10, nº 2, pp. 265-286 
La COVID-19 en las portadas de los diarios de difusión nacional en España

complementa con otros medios ya que los informativos audiovisuales también se hacen eco de las primeras páginas de los diarios y las noticias de primera se leen dos veces más que las de páginas interiores.

De esta forma, la definición de los contenidos de la portada contribuye al establecimiento de la agenda setting, el proceso por el que los medios presentan de forma más frecuente y relevante ciertos temas que el público percibe más importantes que otros (McCombs, 2006). En una situación de crisis sanitaria global, con repercusiones sociales y económicas desconocidas hasta ahora, como la que se aborda en este estudio, el análisis de las portadas permite observar qué asuntos 0 agentes se incluyen en esa agenda mediática.

\subsection{Las crisis sanitarias en los medios de comunicación}

El tratamiento de las crisis sanitarias por parte de los medios de comunicación ha sido abordado en diferentes ocasiones junto con la política comunicativa de las autoridades sanitarias. En el caso de los medios españoles se han analizado la cobertura mediática de diversas crisis como la denominada "de las vacas locas" sucedida en el año 2000 (Francescutti, 2003) o la gripe A de 2009 y la bacteria E. Coli (Villafranca, 2012). Destacan en el estudio de la información sanitaria y sus crisis los denominados Informe Quiral (2008), que desde hace casi dos décadas han estudiado la cobertura informativa tanto de diversas enfermedades como algunas crisis.

La más reciente de estas situaciones de emergencia sanitaria en España fue la crisis del Ébola, ocurrida en 2014, objeto de diversos análisis en cierto modo similares al que se acomete en este trabajo, aunque con diferencias. Por ejemplo, González y Cambra (2015) analizan el tratamiento de esta crisis en los principales diarios de tirada nacional mientras que Monjas-Eleta y Gil-Torres (2019) abordan el estudio tanto de las portadas de prensa nacional y regional como la comunicación institucional por parte del Ministerio de Sanidad.

La aparición y propagación de una grave enfermedad infecciosa constituye un paradigma de crisis informativa, entendida como una situación que "se produce por sorpresa, altera bruscamente los hábitos profesionales cotidianos y exige un esfuerzo extra de recursos humanos y técnicos para cubrir con eficacia la emergencia informativa" (Quesada, 2007: 7).

Existen dos patrones básicos de cobertura periodística de las crisis sanitarias que fueron definidos ya en 2008: patrón crónico y patrón agudo. El patrón agudo "consiste en un tipo de cobertura rápida, poco especializada, pero de gran impacto mediático. El patrón crónico describe un tipo de tratamiento periodístico, de menor impacto, pero más especializado y elaborado" (Revuelta y de Semir, 2008: p. 110).

En la misma línea, Martínez Solana (2004) distingue la información sobre patologías de patrón crónico y agudo. Las patologías de patrón crónico son: "aquellas con repercusión importante sobre la calidad de vida y que están siendo sometidas a 
La COVID-19 en las portadas de los diarios de difusión nacional en España

investigación desde hace varios años". También tienen como característica el que "se aprecia un seguimiento informativo continuado y constante, un nivel de especialización superior a lo habitual, el objeto de la noticia suele estar más trabajado y existe una menor tendencia al sensacionalismo, así como una mejor utilización de las fuentes informativas" (Gómez Martín, 2012: 42).

Por otra parte, la información sobre patologías de patrón agudo se caracteriza por: "trastocar la normalidad durante un corto periodo; a pesar de lo cual poseen un poder de atracción mediática muy elevado. La mayoría de los casos suelen desaparecer de los medios de forma brusca, aunque, en determinadas ocasiones, existe tendencia a la cronificación. Otra de las características del subgrupo es que su efecto mimético es alto (las informaciones suelen ser, prácticamente, idénticas), dándose una mayor tendencia al sensacionalismo y constatándose un menor rigor en la utilización de las fuentes" (Gómez Martín, 2012: 43)

La información sobre la COVID-19 que se analiza en el presente trabajo debido a sus especiales características, por el número de afectados, la duración en el tiempo y las consecuencias económicas, políticas y sociales, participa de las características de los dos patrones. En un primer momento la información podría considerarse de patrón agudo y de hecho cumple los parámetros definidos en el Informe Quiral 10 años (Revuelta y De Semir, 2008) por el gran número de afectados, es noticia en el momento en el que se conoce su existencia, posee consecuencias negativas para la salud y la economía; imprevisibilidad; proximidad a pesar de que el inicio de la pandemia fuera en un país alejado de nuestro entorno; notoriedad por la implicación de numerosos personajes conocidos o infección de mandatarios internacionales.

Sin embargo, la extensión en el tiempo de la pandemia del coronavirus y sus consecuencias hace que, por su duración le hace asumir características del patrón crónico. Los medios de comunicación, y concretamente la prensa en el caso de este estudio, incluyen en el tratamiento informativo de este tema no sólo información de última hora o de actualidad, sino que elaboran contenidos con una mayor especialización y mayor rigor en la utilización de fuentes.

Las especiales características del tratamiento informativo de esta crisis por el uso de redes sociales (Pérez-Dasilva et al., 2020), la viralización de bulos y la infoxicación y sobreinformación (Masip et al, 2020), ha sido reflejado en un término de nuevo cuño, infodemia o infodemic en inglés, que ya ha sido objeto de algunos artículos (Cinelli et al, 2020). El exceso y la baja calidad de la información repercute en la visión distorsionada de una situación crítica provocada por una enfermedad infecciosa que suele derivar en una alerta exagerada en la población que produce temor e incertidumbre y llega a todos los ámbitos desde el social al económico pasando por el político.

Otro elemento relacionado en el tratamiento informativo de las crisis sanitarias es el sensacionalismo, tanto en el tratamiento de las imágenes como en el propio texto (Andreu-Sánchez y Martín-Pascual, 2020). El discurso del miedo a través de un vocabulario alarmista es otra de las características de la información en las crisis, fruto

Revista de Comunicación y Salud, 2020, Vol. 10, ํㅡ 2, pp. 265-286 
La COVID-19 en las portadas de los diarios de difusión nacional en España

también de la tendencia generalizada de los medios de comunicación al 'infotainment'. La apelación a una emoción básica como es el miedo se convierte en un recurso para la búsqueda de una mayor audiencia ya que la presentación de una noticia como peligrosa provoca incertidumbre y aumenta el deseo del público de revelaciones (Monjas-Eleta y Gil-Torres, 2019).

La crisis sanitaria que golpeó durante a España desde el pasado mes de marzo supuso un desafío en todas las áreas en las que se desarrolla la vida humana. El periodismo no ha sido ajeno a estos cambios y la crisis ha puesto de manifiesto, como señalaba Álex Grijelmo (2020), la importancia del periodismo en estas situaciones ya que "cumple un papel esencial, porque sirve como vehículo para transmitir informaciones vitales: qué conviene hacer, cómo cuidarse, qué precauciones domésticas se han de tomar, qué se permite y qué se prohíbe, qué avances se van conociendo en la investigación científica sobre el caso".

\section{OBJETIVOS}

Conocer cuáles han sido los temas noticiosos para los medios, así como analizar la evolución de sus portadas para ver la importancia de la pandemia a lo largo misma, hace que se pueda obtener un reflejo de lo ocurrido durante ese periodo de tiempo y se puedan sacar conclusiones acerca del momento que el oficio periodístico vive en la actualidad y cómo ha reaccionado ante esta situación. Con perspectiva, habría que preguntarse si la COVID-19 atraía ya la atención de los periódicos a finales de febrero, si ocupaba un lugar destacado o quiénes eran los protagonistas de las noticias que se incluían en estas portadas. También percibir si era común la utilización de datos numéricos y cifras para mostrar el avance del virus y si centraban la repercusión del impacto de la pandemia en el aspecto sanitario y social o, por el contrario, en el ámbito político y económico. Además, debido a la variedad de medios, comprobar si existían diferencias notables en las cabeceras respecto a los asuntos informativos seleccionados y los protagonistas.

Por ello, el objetivo principal de este artículo es analizar, conocer y examinar cómo ha evolucionado el tratamiento mediático de la pandemia originada por la COVID-19 en España a través de las portadas de los cinco principales diarios de tirada nacional: El País, El Mundo, ABC, La Razón y La Vanguardia.

Además del objetivo principal marcado en esta investigación de analizar, conocer y examinar cómo ha evolucionado el tratamiento mediático de la pandemia originada por la COVID-19 en España a través de las portadas de los cinco principales diarios de tirada nacional (El País, El Mundo, ABC, La Razón y La Vanguardia), se establecen otros objetivos específicos que ayudarán a comprender la utilización de diversos métodos en las portadas de los diarios para plasmar una misma realidad: (1) Conocer qué tipo de información aportan cada uno de los medios dependiendo de su línea ideológica; (2) Examinar si, en sus portadas, coinciden a la hora de destacar un acontecimiento concreto o difieren en establecer el hecho más novedoso del día; (3) Establecer cómo plasman la evolución de la pandemia y observar en qué dirección 
La COVID-19 en las portadas de los diarios de difusión nacional en España

apuntan cada uno de ellos a la hora de mostrar una misma realidad; (4) Observar cuánto espacio y qué formato dan a la información relacionada con la COVID-19 dentro de la organización habitual de sus portadas; y (5) Descubrir si se producen cambios a lo largo del periodo analizado a la hora de reflejar el desarrollo de la enfermedad dentro de la sociedad española en las portadas de estos diarios.

\section{METODOLOGÍA}

De acuerdo con los objetivos anteriores, las hipótesis que se plantean en esta investigación acerca de la evolución de la COVID-19 en las portadas de los principales diarios españoles de tirada nacional son:

H1. Los contenidos acerca de la COVID-19 ganan protagonismo y ocupan más espacio en las portadas con el paso de las semanas con necesidad de incluir gráficos e infografías sobre el número de contagiados, víctimas mortales y otros datos estadísticos del impacto de la pandemia.

H2. Los asuntos abordados en las portadas de los diarios varían con el tiempo. Se pronostica que en la primera semana analizada en febrero las portadas se centran mayoritariamente en información internacional sobre el virus, en marzo se aborda principalmente la cuestión sanitaria y en abril ganan peso las informaciones sobre el impacto de la pandemia en la política y economía españolas.

H3. Los diarios acompañan las informaciones de sus portadas con fotografías en las que el protagonismo recae en la mayoría de las ocasiones sobre figuras políticas.

Pese al descenso del impacto tradicional de la prensa como método de información del público general tras la llegada de Internet, la cuota de audiencia se mantiene en un $20 \%$ con respecto al total analizado por el Estudio General de Medios en su primer trimestre de 2020 (AIMC, 2020). Aún con esta cifra de audiencia, los datos de la Oficina de Justificación de la Difusión (OJD) hablan de una bajada generalizada en todos los rotativos, tendencia repetida casi desde la llegada de la información digital (Dircomfidencial, 2020). El análisis de contenido se realiza en una muestra seleccionada constituida por las primeras páginas o portadas de los cinco principales diarios de tirada nacional en España con edición en papel: (1) El País, como el diario con mayor difusión nacional en papel con 110.000 ejemplares diarios por día; (2) La Vanguardia, el segundo diario con 88.255 ejemplares diarios; (3) El Mundo, con difusión promedio de 80.600 copias diarias; (4) $A B C$ que alcanzó una difusión de 68.700 ejemplares; y (5) La Razón que cerró el año con 51.537 ejemplares diarios.

La elección de las portadas de prensa como unidad de análisis se debe a que es un espacio donde se observa de forma muy clara la selección y el orden de importancia que el periódico otorga a las informaciones periodísticas del día. Por ello, el estudio de las portadas constituye un elemento básico para conocer el enfoque que cada diario adopta en el proceso de construcción de la realidad social (Palau Sampio, 2013).

En el caso de la COVID-19, existen ya estudios sobre las portadas de prensa que abordan el cumplimiento de los principios éticos del periodismo en la cobertura de esta 
crisis como el de Maciá Barber (2020), que difiere del que se presenta en que estudia principalmente la cobertura fotográfica mientras que este trabajo aborda el léxico y los titulares. Otro artículo, de Fusté-Forné (2020), estudia las portadas de tres diarios en el periodo previo al Estado de Alarma, mientras que este trabajo aborda un periodo más amplio, hasta el mes de abril, en cinco diarios.

Por todo ello, un análisis de las portadas se ha considerado un estudio interesante para analizar la reacción de la prensa en esta crisis sanitaria y así observar la evolución de la información sobre la COVID-19 antes de la declaración del Estado de Alarma y durante el desarrollo de parte de esta. Se seleccionan los meses de febrero (cuando ya era un tema recurrente en los medios de comunicación), marzo (estado de alarma) y abril (mes de total confinamiento de la población con los datos más elevados de contagios y fallecidos). Las fechas seleccionadas corresponden a las últimas semanas de los citados meses: 22 al 29 de febrero, del 24 al 31 de marzo y del 23 al 30 de abril. Por ende, la muestra total seleccionada comprende 120 portadas analizadas.

La ficha de análisis contiene tres bloques que permiten analizar los principales elementos de la portada con los que el diario determina la mayor o menor relevancia de una información. El primer bloque contiene los datos generales (diario, fecha de publicación). El segundo bloque analiza los aspectos formales: medición del espacio que ocupa en la portada del diario, parámetros como la ubicación, el número de columnas que ocupa o la extensión que alcanza en la portada y complementos gráficos que acompañan como una infografía o algún otro complemento. Todos estos parámetros revelan la valoración que el diario hace de una información, por ejemplo, las noticias más relevantes se ubican en la parte superior, siguiendo el triángulo de Haas, y, al tratarse de la primera página, en la zona izquierda, al contrario que las páginas impares del interior del periódico. Las noticias excepcionales se titulan en la primera página a todo el ancho, cinco columnas según el formato tabloide y de lectura horizontal en España, y según se reduce su importancia se reduce también su anchura. Y si va acompañada de de fotografías o infografías también será más importante que las que no la llevan (Berrocal Gonzalo y Rodríguez Maribona, 1998) El tercer bloque de la ficha de anáisis se refiere al contenido de la portada: se especifican tres subgrupos para cada uno de los elementos que se pretende analizar: 3.1. Fotografía, se indica el protagonismo de la fotografía relacionada con la información acerca de la COVID-19; 3.2. Titular, se incluye tanto el asunto informativo del titular principal como el protagonista de este; y 3.3. el léxico utilizado para expresar esa noticia relacionada con el coronavirus. Observar el protagonismo que el diario otorga en sus titulares y fotografías, así como los asuntos que selecciona, resulta clave para comprender los temas y actores socialmente más sobresalientes de la agenda mediática (McCombs, 2006).

\section{DISCUSIÓN}

Revista de Comunicación y Salud, 2020, Vol. 10, nº 2, pp. 265-286 
La COVID-19 en las portadas de los diarios de difusión nacional en España

Este epígrafe presenta los resultados obtenidos tras la aplicación de la ficha de análisis a las 120 portadas de los diarios en los días analizados.

\subsection{Resultados de la semana del 22 al 29 de febrero}

En el mes de febrero, el 62 ' $5 \%$ de las ocasiones, los diarios analizados incluyeron información relacionada con la COVID-19 entre 1/4 y 2/4 de portada. Además, tan sólo el $10 \%$ de las veces no han incluido ninguna información sobre la evolución de la expansión del virus. La ubicación de la información ha sido muy variable sin destacarse ninguna zona por encima del resto siendo la más utilizada la información ubicada en la parte superior izquierda (22'5\%). En la mayor parte de las ocasiones (80\%) se encuentra información acerca del coronavirus con un ancho de entre tres y cinco columnas. Sin embargo, en esta última semana del mes de febrero existían una menor conciencia de la importancia de la expansión de la COVID-19 en España, por lo que la información no alcanzaba excesiva relevancia y sólo encontramos información sobre el virus a portada completa el $5 \%$ de las veces (2 portadas de 40 que comprenden el mes analizado).

Respecto al análisis de las portadas, hay que señalar también las diferencias de diseño entre los diferentes periódicos. Así, por ejemplo, la configuración de las portadas del diario La Vanguardia es diferente a las de otros diarios analizados. Las noticias principales de la portada se destacan con un recuadro que las distingue del resto de informaciones incluidas en la portada, pero, a pesar de ser la noticia principal, en algunas ocasiones no incluyen fotografía. La Vanguardia propone un formato de conglomerado de titulares con uno genérico o más amplio, y varios que secunden la información principal junto a las entradillas. Sin embargo, en este periodo analizado de la primera semana de febrero, se detectan tres días en los que se coronavirus alcanza los tres cuartos de portada. Además, abunda la extensión de entre cuatro y cinco columnas lo que indica que se suelen presentar ocupando todo o casi todo el ancho de portada.

También es diferente la portada del diario $A B C$, debido a su formato arrevistado, a menudo, una sola imagen ocupa prácticamente la totalidad de la portada y es recurrente el uso, no sólo de fotografías, sino de ilustraciones o montajes de imágenes. La primera semana de análisis $A B C$ incluyó información sobre el coronavirus cuatro días y en tres de las portadas, el coronavirus ocupaba todo el espacio. En dos ocasiones el asunto principal fueron las repercusiones económicas de la enfermedad: el 25 de febrero la portada es un montaje con unos billetes con los personajes tapados con mascarilla y el 29 de febrero una fotografía de los trabajadores de una bolsa asiática que llena la portada. La tercera portada completa sobre la COVID-19 (23/02/20), se centró en la situación en el norte de Italia con una imagen de una ambulancia con sanitarios con equipos de protección y un paciente. El escenario italiano también aparece el día 24 de febrero con la imagen en un faldón superior de un hombre con un antifaz veneciano y una mascarilla que simboliza el cierre del Carnaval de la ciudad de los canales por el coronavirus. 
En cuanto al apartado visual, se encuentra equilibrado entre las portadas que llevan fotografía actual (la mitad de las portadas de febrero) y las que no llevan ninguna fotografía asociada (40\%). En su mayoría, en este mes no se ha incluido ni infografías ni otros complementos que complementen las informaciones de la COVID-19. El protagonismo de la fotografía, como se refleja en el Gráfico 1, en febrero se centra en los ciudadanos que aparecen reflejados en ellas un 27 ' $5 \%$ de las ocasiones.

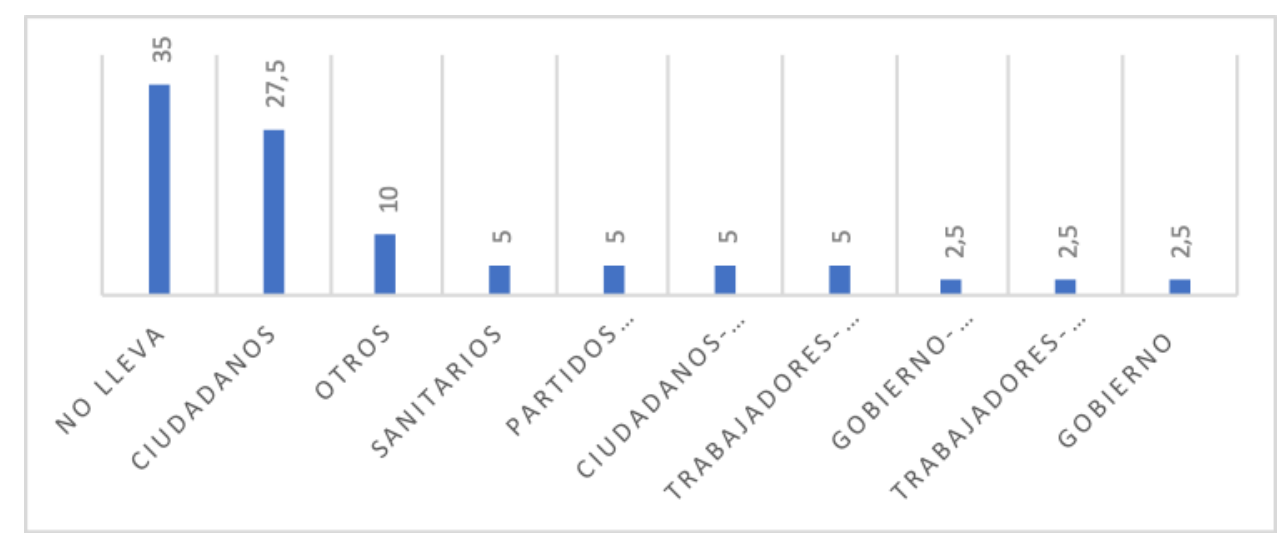

Gráfico 1. Protagonistas fotografías COVID-19 en portadas febrero 2020

Fuente: Elaboración propia

El asunto informativo del titular principal, recogido con detalle en el Gráfico 2, sobre coronavirus se enfoca en su mayoría a temas económicos (15\%), sobre todo las caídas del mercado bursátil internacional así como a la política y las comunidades autónomas (12'5\%), como por ejemplo los datos de contagios del coronavirus en nuevas zonas de Barcelona (La Vanguardia, 26 y 27/02/20) o la evolución de los contagios en España y el impacto económico de las medidas del ejecutivo español (El Mundo, 27/02/20). La expansión del virus en otros países y los problemas causados en ellos suponen un $10 \%$ de las informaciones de portada que abordan principalmente la situación en Italia aunque también sobre países asiáticos como Corea del Sur (El Mundo, 26/02/20). 
La COVID-19 en las portadas de los diarios de difusión nacional en España

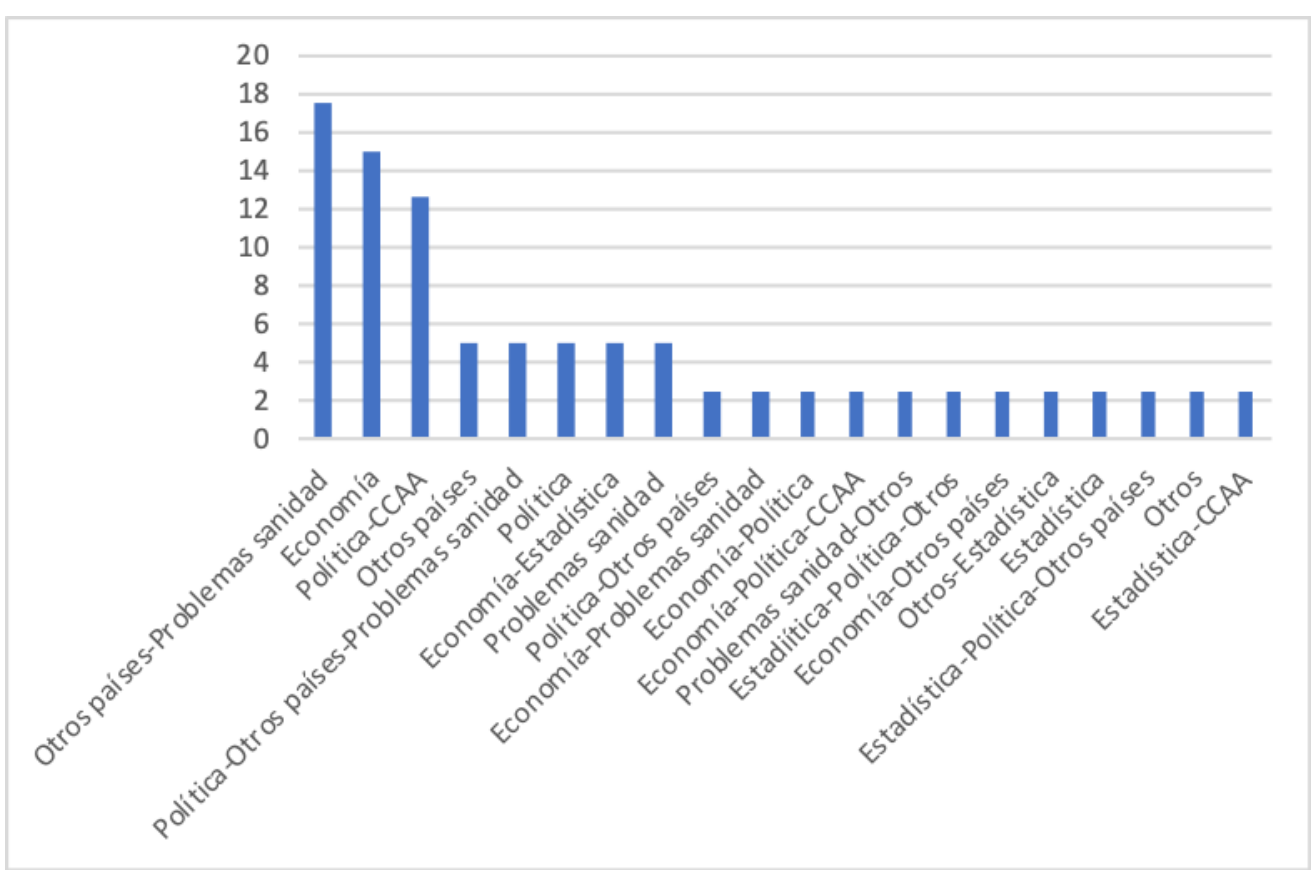

Gráfico 2. Asunto titular principal relacionado con la COVID-19 en portadas febrero 2020

Fuente: Elaboración propia

Por su parte, el protagonista del titular se centra en diversas personalidades, autoridades y otros protagonistas como el gobierno italiano o los reyes de España (40\%) mientras que el 27 '5\% se centra en el gobierno español.

Otro de los aspectos analizados, el léxico, hace referencia en su mayoría a un vocabulario de pandemia y crisis, tanto sanitaria como económica al hablar de las caídas en bolsa. El vocabulario refleja la gravedad de la situación. Por ejemplo, se utilizan expresiones como "Alerta máxima en Italia tras 76 contagios de coronavirus y dos muertos" (El País, 23/02/20), o referidas al miedo como "El pánico al coronavirus contagia a la bolsa" $(A B C, 25 / 02 / 20)$ o "La OMS teme turbulencias sociales por el coronavirus" (La Vanguardia, 23/02/20). Abundan los adjetivos superlativos como "máxima" en muchos de los titulares como en La Razón (23 y 29 / 02/20).

\subsection{Resultados de la semana del 24 al 31 de marzo}

El mes de marzo cambia de manera notoria la forma de informar de todos los diarios analizados con respecto a la COVID-19 en consonancia con su impacto en España. Tanto es así que, durante este periodo, el $100 \%$ de las portadas fueron ocupadas en su totalidad por informaciones relacionadas con la COVID-19 ubicándose más de la mitad de los titulares principales de estas noticias en la zona superior izquierda (52'5\% de las veces). Además, en más del $75 \%$ de las ocasiones (6 de cada 8 ) las informaciones principales sobre coronavirus se extendían a lo largo de 4 o 5 columnas. En los diarios analizados la noticia principal sobre la COVID-19 ocupaba un cuarto de portada en el 
$75 \%$ de las veces debido a la gran cantidad de informaciones relacionadas con este asunto que hizo que los diarios optasen por dar cabida a muchas informaciones en portada, en detrimento de la principal. Tan sólo en $A B C$, por su particular configuración de la portada en la que normalmente solo se destaca una información, no se cumple esta tendencia.

En el análisis de la parte visual de las portadas, se observa que, durante el mes de marzo, los diarios utilizan fotografías de actualidad en casi todas sus portadas (90\%) frente a las de archivo o a la combinación de ambas, entre las que destaca la portada de $A B C$ del día 26 de marzo con una imagen de la manifestación del día de la Mujer el $8-\mathrm{M}$, por su relación con la expansión del contagio del virus. El 100\% de las imágenes de portada en este periodo analizado se refieren a la COVID-19.

El protagonismo de las imágenes principales que acompañan a la información destacada sobre coronavirus, que puede verse en el Gráfico 3, lo centran de forma mayoritaria los ciudadanos (22'5\%), en diversa forma y medida de retratarlos, incluso para destacar la ausencia de vida en las calles, la imagen de portada de El País del 29 de marzo retrata una Gran Vía desierta con tan sólo una anciana cruzando la calle. Los sanitarios suponen el $17{ }^{\prime} 5 \%$ de las portadas, en ocasiones para denunciar la falta de medios de protección, como el montaje de cuatro fotografías de la portada de $A B C$ del día 25 de marzo.
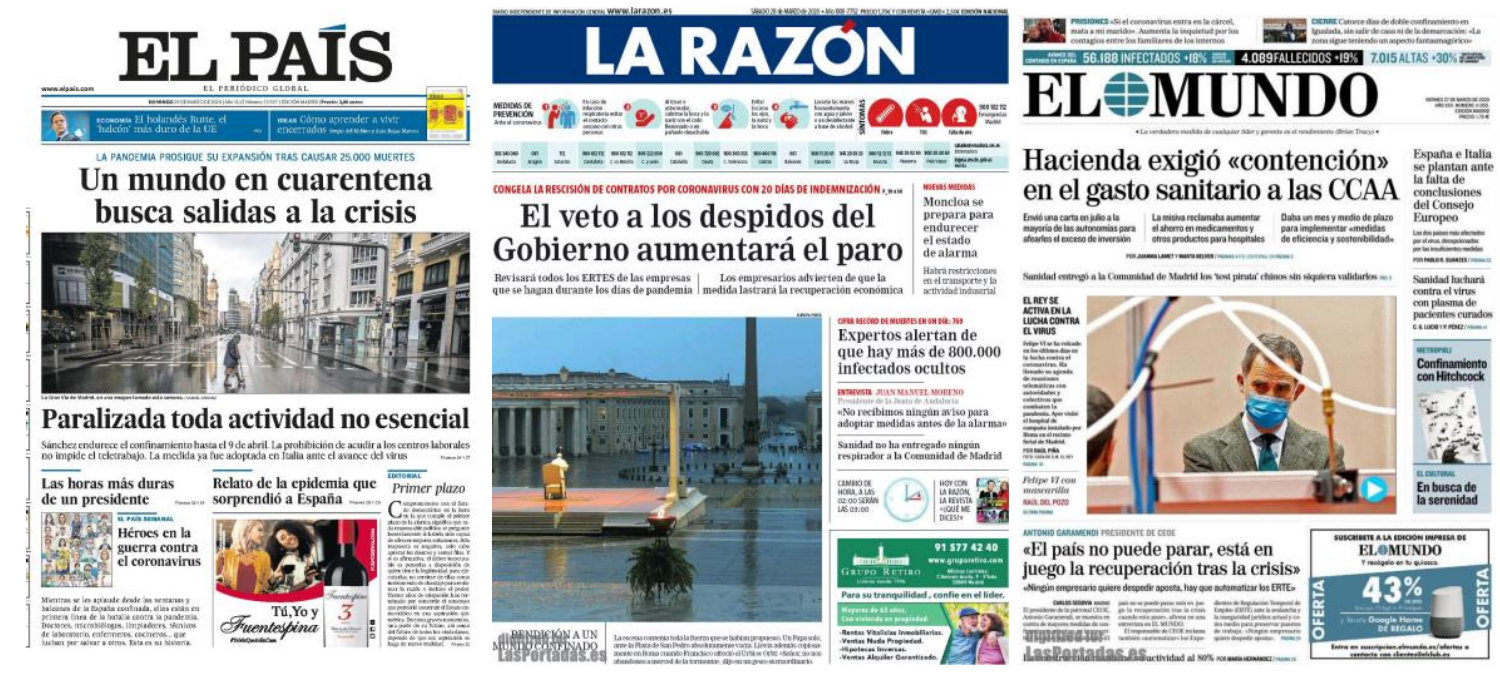

Figura 1. Portadas El País (29/03/20) La Razón (28/03/20) y El Mundo (27/03/20) .

Fuente: lasportadas.es

Otras personalidades, instituciones y autoridades que han ocupado el protagonismo de las instantáneas en un $20 \%$, como por ejemplo el Papa Francisco, que pronunció la bendición Urbi et Orbe en una insólita plaza de San Pedro vacía que fue imagen de portada el día 28 de marzo en El País, La Razón y La Vanguardia. O la visita del rey Felipe al hospital de campaña de Ifema, que fue portada el 27 de marzo en todos los diarios analizados, excepto La Vanguardia. También los líderes políticos nacionales son 
imagen de portada, el 26 de marzo, El Mundo lleva a primera al presidente del Gobierno en el Congreso y el líder del PP, Pablo Casado, ocupa la portada del 31 de marzo en $A B C$.

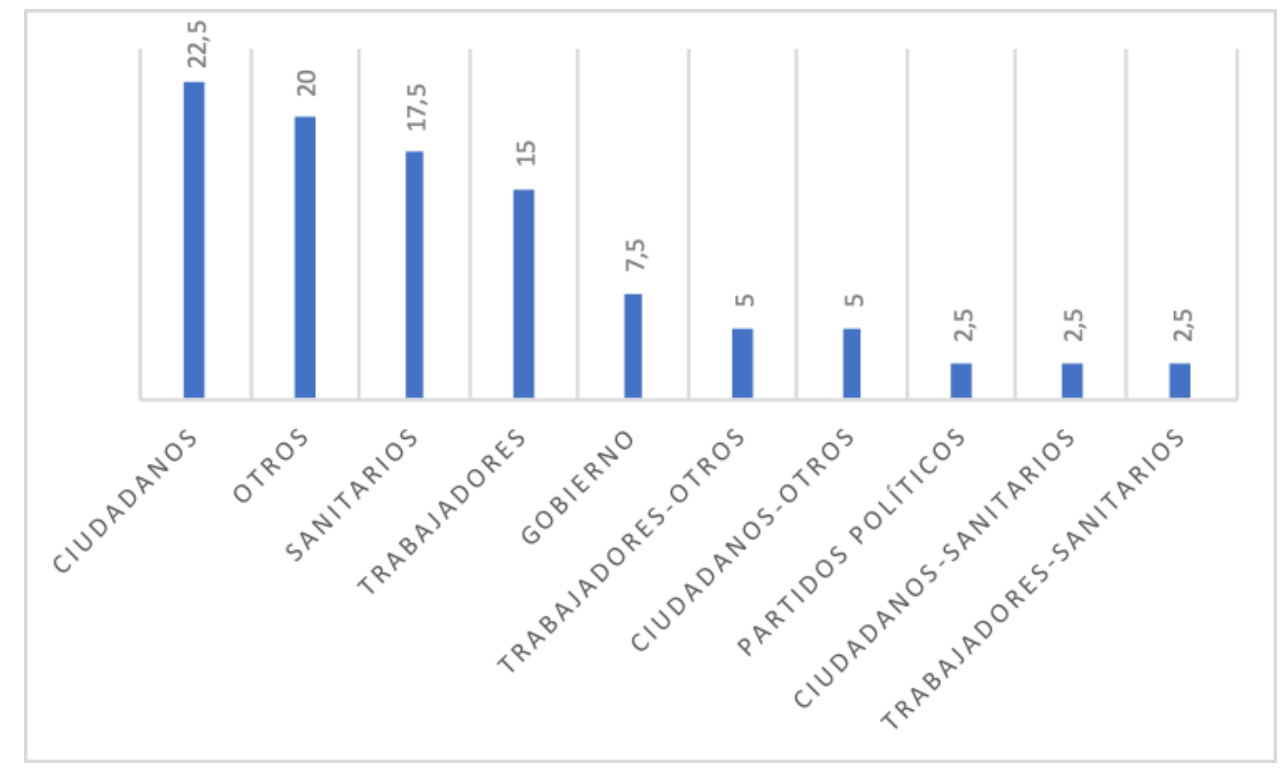

Gráfico 3. Protagonista de la fotografía de portada Covid-19 -marzo 2020

Fuente: Elaboración propia

También en este mes se incluyen en los diarios El Mundo y La Razón, diferentes infografías que destacan apartados estadísticos e informan sobre síntomas y medidas de protección consulta en señal de apoyo para frenar la lucha contra el coronavirus. El $65 \%$ de las veces se incluye esta información complementaria a los titulares, así como el $35 \%$ de las portadas no llevan ninguna infografía. No se encuentran otros complementos por lo general (87'5\%), sin embargo, en ciertas ocasiones se incluyen apartados de análisis y opinión sobre la pandemia (12’5\% de las veces).

El asunto informativo de los principales titulares de las portadas analizadas en el mes de marzo apunta que los temas de política en materia económica han ocupado el $30 \%$ de las informaciones principales en relación con la crisis y medidas a consecuencia de la pandemia de COVID-19. Aunque este tema sea el más destacado, la política por sí misma con medidas, diferencia de posturas y críticas, ha estado presente en el $20 \%$ de las ocasiones por lo que se podría afirmar que la política ha ocupado la mitad o más de las informaciones principales sobre COVID-19. Fruto de ello, en el análisis realizado se muestra que, en más de la mitad de los titulares principales relacionados con coronavirus, el gobierno es el protagonista ya sea su presidente, vicepresidente o vicepresidenta o ministro de Sanidad (57'5\%). También destaca que otras autoridades, personalidades e instituciones (10\%) estén igual o por encima en protagonismo de las principales informaciones sobre la pandemia que los sanitarios $(5 \%)$ o los ciudadanos $(10 \%)$.

El léxico apreciado en los titulares principales de este mes analizado se centra en la crisis ya que se ubica vocabulario relacionado con este concepto en 11 de las 40 
portadas de marzo. Además, otras veces va asociado a la palabra alarma (17'5\%) o pandemia (12'5\%). Pero también, y en consonancia con la predominancia de la política entre los asuntos abordados, se utilizan términos o expresiones que implican una mayor valoración y crítica de las actuaciones, principalmente del Gobierno. Por ejemplo, en antetítulos como en La Razón ("La dejación de Moncloa ante el Covid-19" (24/03/20) o en El Mundo, la palabra "desoyó" (25/03/2020) o "caos" (24/03/20) 0 "improvisa"(30/03/20) referida al presidente del gobierno, así como "bandazos" en el antetítulo para definir las medidas del ejecutivo en la crisis del coronavirus. En $A B C$ el lenguaje utilizado denota disputa o beligerancia en las portadas de temática política como la que versa acerca del desacuerdo entre vicepresidentes el día 28 al utilizar la expresión "impone" entre Iglesias y Calviño o la "lealtad sí, pleitesía, no" del titular de la portada del día 31. Igualmente, se encuentra cierto tono de reproche en las portadas del 26 ("El gobierno ya lo sabía"), 29 ("Sánchez elige parar la economía") y 30 ("Sánchez hiberna la economía y desoye a los empresarios") a las medidas o acciones del gobierno.

\subsection{Resultados de la semana del 23 al 30 de abril}

El último período analizado en esta investigación, el mes de abril, deja prácticamente la misma tendencia que el mes anterior. El 97'5 por ciento de las portadas llevan informaciones sobre la COVID-19 en página completa dejando el restante en informaciones a un cuarto de portada (tan sólo una portada del diario La Vanguardia no sigue la tendencia de página completa). Además, el $60 \%$ de las ocasiones, el titular principal sobre este asunto se sitúa en la zona superior izquierda de la portada ubicándose el $11 \%$ en la parte inferior del mismo lado. Esto deja un total de más del $70 \%$ de titulares principales sobre COVID-19 en la zona izquierda de la portada. Más de la mitad de estos ocupan cuatro columnas (55\%) siendo la segunda tendencia más observada la de tres columnas (17'5\%). Al igual que en el mes de marzo, las informaciones principales, pese a su extensión a lo ancho, ocupan en la mayoría de las ocasiones (90\%) un cuarto de portada debido a la gran variedad de contenidos sobre la pandemia que se incluyen en las portadas de este periodo.

El apartado gráfico destaca que un $90 \%$ de las portadas acompañan su información escrita con fotografías relacionadas con la COVID-19. De ellas, el 87'5 por ciento son de actualidad ya sean montajes fotográficos (propios de $A B C$ y que pueden verse en la Figura 2), ilustraciones o instantáneas dejando un 2'5\% a fotografías de archivo. El 62'5 por ciento de las ocasiones, casi como en el mes de marzo, los diarios recurren a infografías para exponer datos acerca de la evolución pandémica o información sobre síntomas y medidas de protección contra el virus. Siguen siendo El Mundo y La Razón los que incluyen este tipo de grafismos al que se le une $A B C$ con un crespón negro adjunto a la cabecera en señal de luto por las víctimas mortales que el coronavirus ha dejado. También se encuentran otros complementos sobretodo de análisis (10\%) aunque la tendencia más habitual es no incluir ningún otro apartado.

El protagonismo de las fotografías que ilustran estas portadas recae en los ciudadanos de forma mayoritaria (35\%) siendo el gobierno el segundo que más 
imágenes protagoniza (17’5\%) y los trabajadores en tercer lugar con un $12{ }^{\prime} 5 \%$ de las ocasiones.
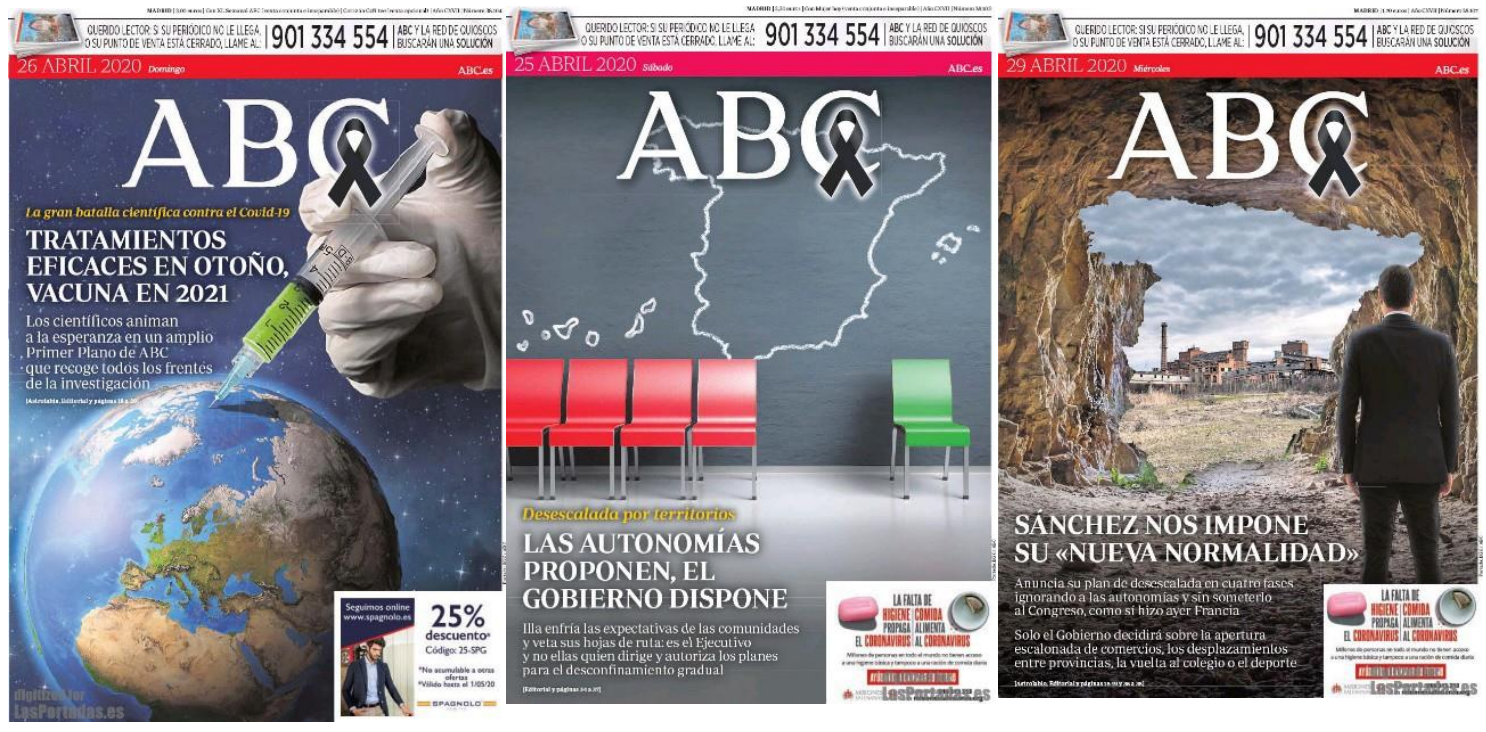

Figura 2. Portadas diario $A B C(25,26$ y 29/04/2020).

Fuente: lasportadas.es

En cuanto a la cuestión informativa tratada en el titular principal, como se detalla en el Gráfico 4, el 37’5\% de las ocasiones se centra en la política bien en decisiones o bien en medidas a aprobar como las fases de desescalada. El segundo tema que más se trata es la política económica, sobre todo en materia de compra de material sanitario y creación del fondo europeo para la reconstrucción de la economía tras la crisis producida por la pandemia en Europa (12'5\%). Por su parte, cuatro de las cuarenta portadas que comprenden el mes de abril han versado sobre otros temas centrados en autoridades e instituciones (10\%).

El protagonismo de los titulares principales sobre COVID-19 en abril, que se detalla en el Gráfico 4, ha sido en su mayoría para el gobierno estando presente en veinte de las cuarenta portadas analizadas (50\%). Además, durante este mes, las CCAA y sus confrontaciones con el gobierno central han protagonizado el 12'5 por ciento de las portadas (5 de 40 ) y los ciudadanos también han estado presentes (10\%) al igual que otras personalidades y autoridades (15\%). 


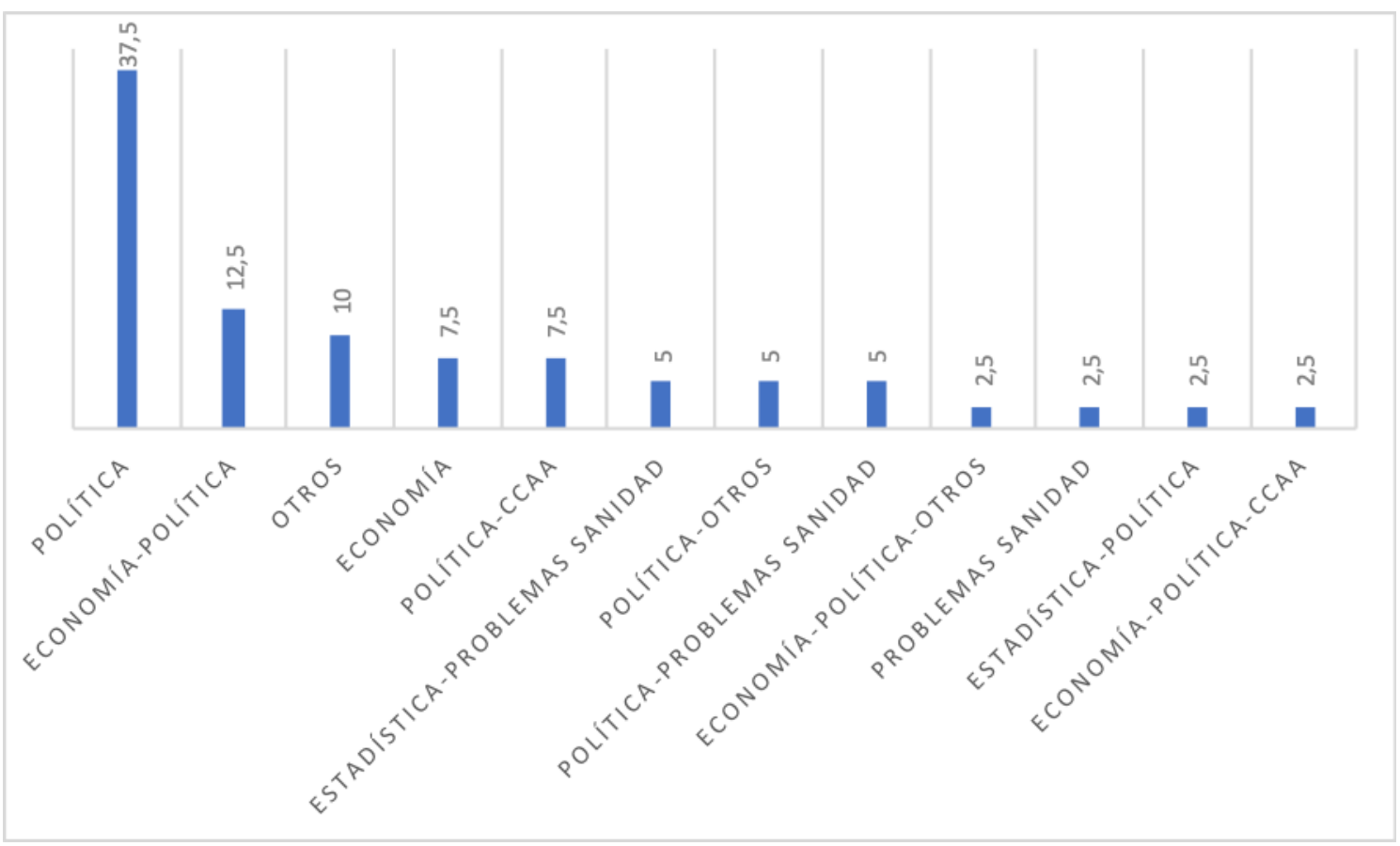

Gráfico 4. Asunto titular COVID-19- abril 2020

Fuente: Elaboración propia

El léxico utilizado para este mes en las noticias principales de las portadas analizadas se ha centrado en un vocabulario relacionado con otros conceptos no incluidos en la tabla de análisis como el reproche, la crítica e incluso la acusación en ciertos medios $(20 \%)$. La crisis $(12 ' 5 \%)$ o la pandemia $\left(12{ }^{\prime} 5 \%\right)$ también han estado presente en el vocabulario de los titulares principales analizados en abril bien sea relacionados con otros conceptos o por separado.

\subsection{Evolución de la información de la COVID-19 en las portadas}

La información sobre la pandemia en las portadas analizadas entre el mes de febrero y abril permite destacar el crecimiento de espacio dedicado a las informaciones sobre el virus y el cambio de formato a medida que han ido pasando los días y la incidencia del virus ha sido mayor, como queda reflejado en el Grafico 5. El crecimiento es destacado entre febrero y marzo, en que se pasa de un $10 \%$ de portadas sin información sobre COVID-19 en febrero a un $100 \%$ de las portadas en marzo de dedicadas al coronavirus de forma completa. La diferencia es aún mayor si se tiene en cuenta el espacio que ocupa la información sobre el coronavirus en febrero, que ocupa entre uno y dos cuartos de portada mayoritariamente. Siguiendo la tendencia a copar las portadas, en abril el $97,5 \%$ de las portadas llevan informaciones sobre la pandemia a portada completa. 
La COVID-19 en las portadas de los diarios de difusión nacional en España

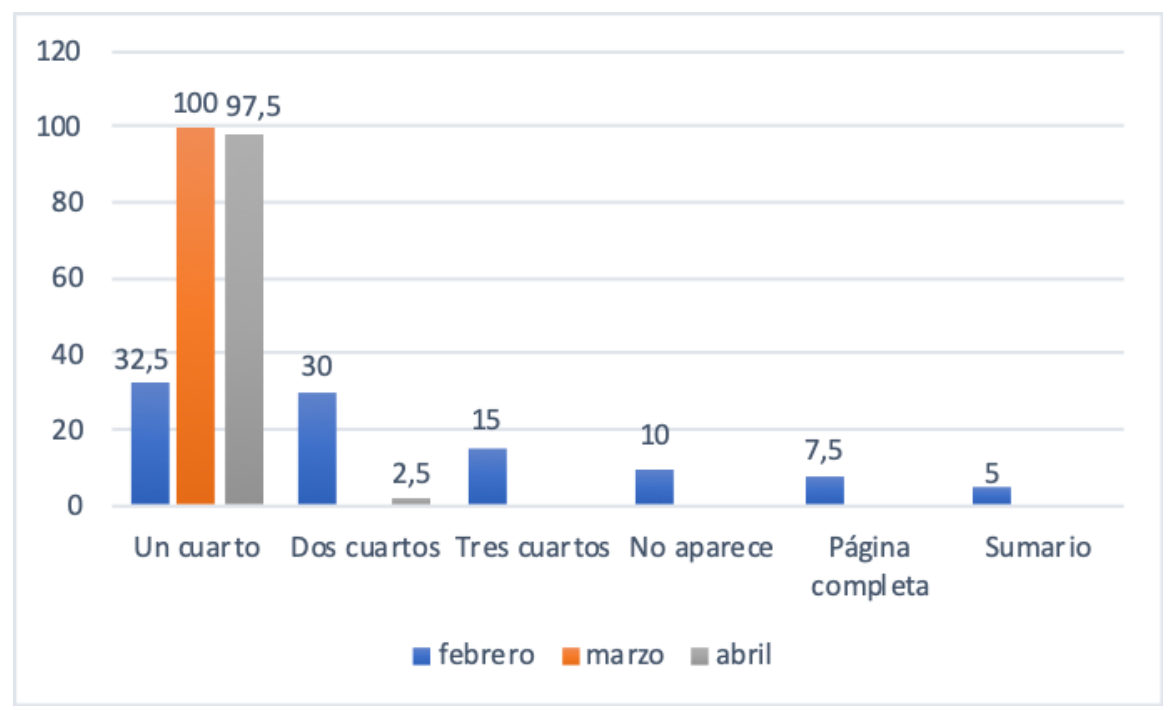

Gráfico 5. Espacio que ocupa la información sobre COVID-19 en la portada Fuente: Elaboración propia

Respecto al uso de infografías en portada para informar de números de teléfono de consulta o datos estadísticos relacionados con la COVID-19 también se pasa de un primer periodo de análisis en febrero en el que no se utilizan estos recursos, a una mayor presencia en las portadas en el mes de marzo, aunque con diferencias entre los periódicos analizados. En el mes de abril, la utilización de este recurso informativo visual se reduce drásticamente. El Mundo utiliza una banda sobre la mancheta para recoger las cifras y porcentajes de infectados, fallecidos y altas tanto en marzo como en abril y La Razón también utiliza gráficos en su portada con síntomas, medidas de prevención, datos y teléfono de emergencias en el periodo analizado en marzo (excepto el día 24) y en abril. Sin embargo, El País no utiliza ningún infográfico en sus portadas en marzo y en abril sólo en una ocasión presenta en la primera página unos gráficos sobre la mortalidad en el territorio nacional (26/04/20). La Vanguardia incluye en el periodo analizado en marzo un cuadro o faldón con las cifras de positivos, muertos y altas en territorio nacional sobre un color amarillo, excepto el 31 de marzo que cambia de color a azul. En abril, este dato desaparece de la cabecera catalana y tan sólo el día 24 de abril hay un gráfico sobre la influencia en la mortalidad en Cataluña entre la gripe y la COVID-19. Por sus peculiares características de portada, $A B C$ no suele incluir gráficos en primera página, aunque en abril incorpora un lazo negro a su mancheta con el nombre del periódico.

Los asuntos abordados en los titulares de la información principal de la COVID-19 se mueven en tres ejes fundamentales con diferentes combinaciones: política, economía y sanidad a los que cabe añadir un asunto más, el relativo a las informaciones sobre el impacto de la pandemia en otros países y que se detalla en el gráfico 6 . El análisis revela también una cierta evolución en los temas abordados en las portadas de los diarios analizados. Mientras que en el mes de febrero, el asunto más tratado fue la expansión del virus en otros países $(17,5 \%)$, en el mes de marzo la economía junto con 
la política acapara el $30 \%$ de los asuntos abordados en los titulares. Esta tendencia a estos dos temas se incrementa en abril donde la economía junto con la política acapara el mayor porcentaje de titulares, $37,5 \%$ los referidos a cuestiones políticas principalmente sobre la gestión de la pandemia por parte del gobierno, y la unión de economía y política suma un 12,5\%, mientras que los asuntos puramente económicos suponen un $7,5 \%$.

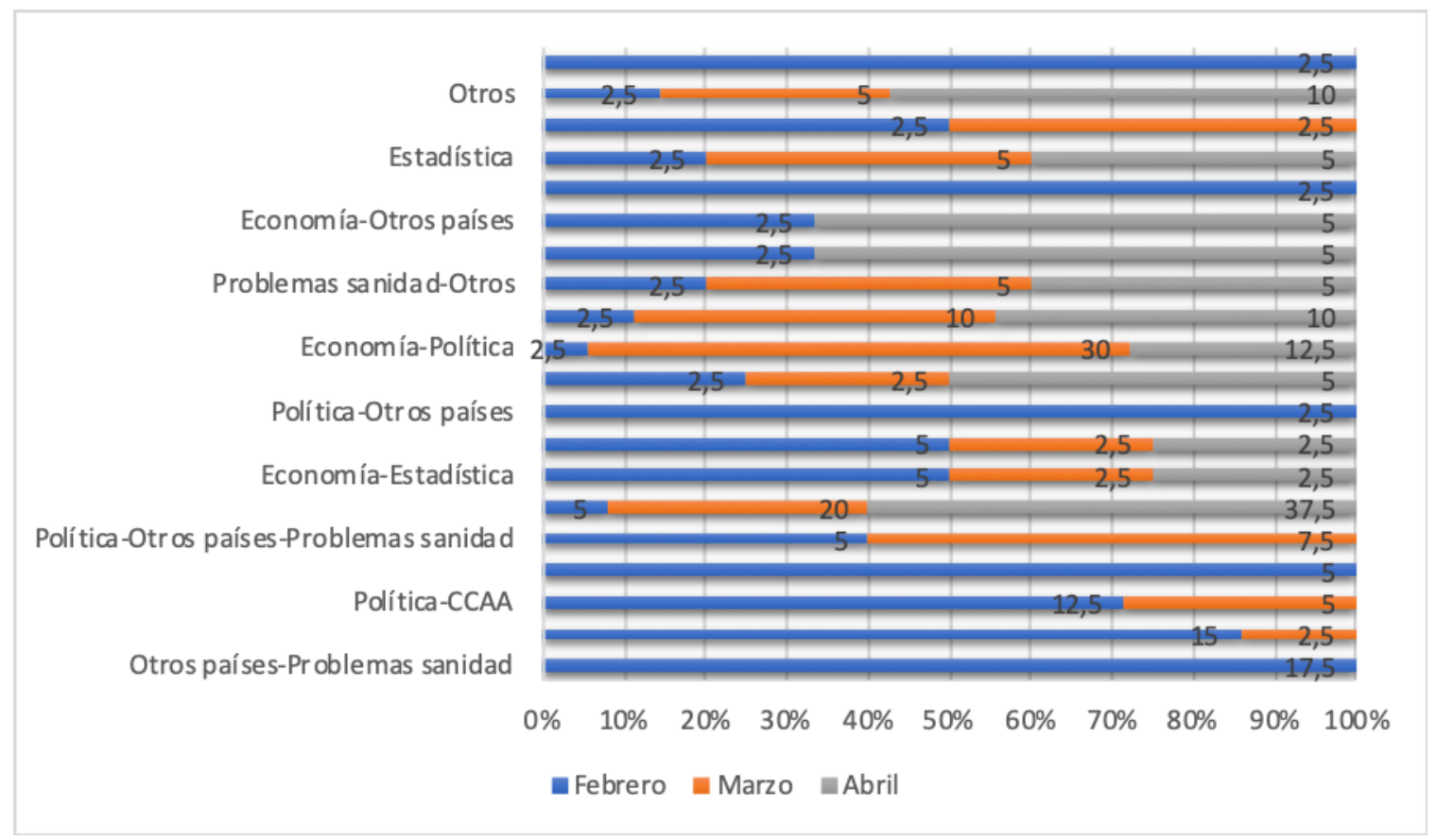

Gráfico 6. Asunto titular principal sobre COVID-19 en la portada Fuente: Elaboración propia

En cuanto a las fotografías, cabe también destacar el dato de febrero en el que un $40 \%$ de las portadas analizadas no llevaba una imagen relacionada con el virus mientras que en marzo el $95 \%$ de las portadas llevan una fotografía, de las que el $90 \%$ es una imagen de actualidad y en abril el $92,5 \%$ de las portadas llevan una fotografía relacionada con la COVID-19 de las que el $8,7,5 \%$ es de actualidad.

Respecto a los protagonistas de las fotografías relacionadas con la COVID-19, los ciudadanos son claramente los protagonistas de las instantáneas. Los ciudadanos son protagonistas en febrero con un $27,5 \%$ de las portadas, también en marzo, con un $22,5 \%$ y en abril con un $35 \%$ de las portadas. En el gráfico 7 , se recogen los datos desglosados, ya que algunas instantáneas combinan protagonistas, como ciudadanos, trabajadores, y sanitarios. Los sanitarios ocupan un lugar desigual en las fotografías de portada. En marzo se sitúan en segunda posición por detrás de los ciudadanos con un $17,5 \%$ mientras que en febrero y abril sólo alcanzan el $5 \%$. A ello cabría sumar las fotografías que están compartidas como hemos señalado y estos datos no vienen sino a reafirmar cómo la sociedad civil se alza como protagonista de la información gráfica. 
La COVID-19 en las portadas de los diarios de difusión nacional en España

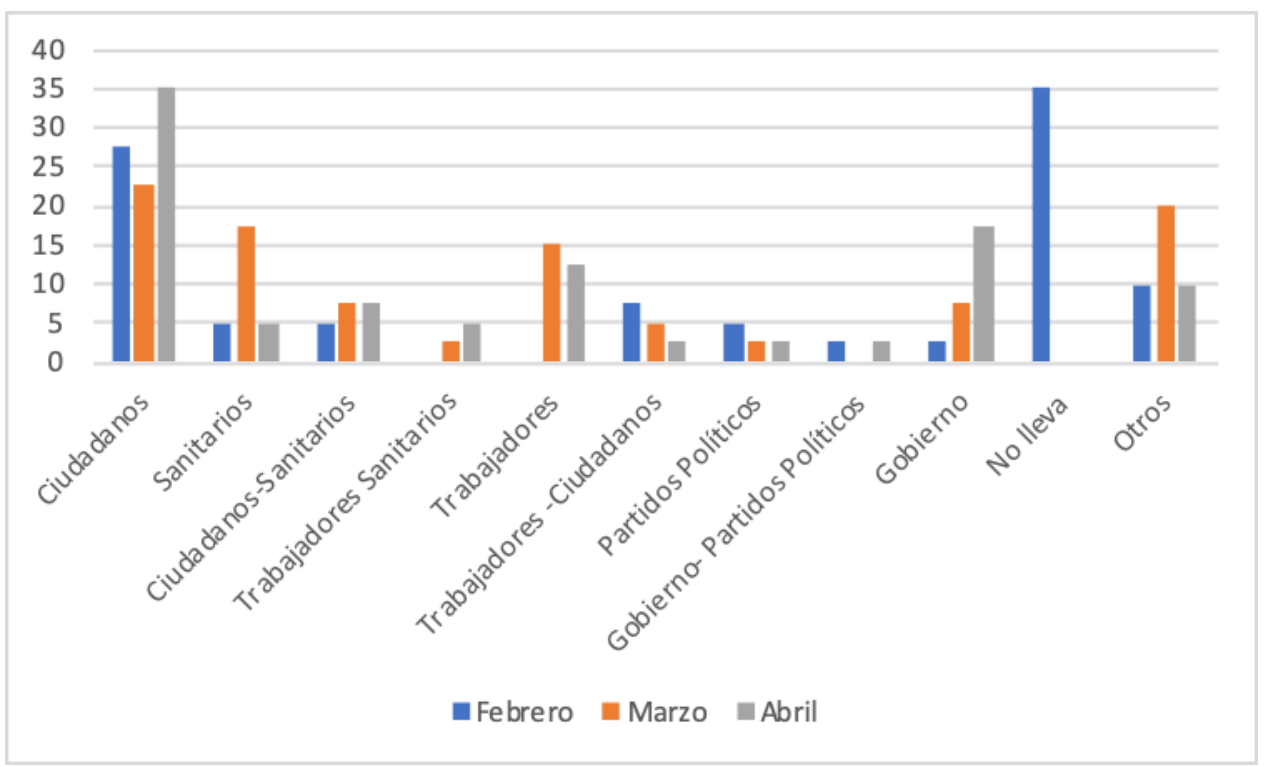

Gráfico 7. Protagonistas de la fotografía sobre COVID-19 en la portada

Fuente: Elaboración propia

Respecto a la representación en las fotografías de portada del Gobierno, ésta ha ido aumentando conforme avanzaba la pandemia y los asuntos a tratar se aproximaban más al debate sobre la gestión política de la crisis. En febrero tan sólo un $2,5 \%$ de las fotografías correspondían a miembros del Gobierno, en marzo el porcentaje aumenta al 7,5 y en abril el incremento es mayor, un $17,5 \%$ de las imágenes corresponden al gobierno encabezado por Pedro Sánchez. Los representantes de partidos políticos ocupan las fotografías de portada en porcentajes del $2,5 \%$ en todos los periodos analizados, aunque cabría sumar algunas instantáneas en las que comparten espacio con el gobierno lo que elevaría el porcentaje un 2,5\% más, dato que resulta comprensible dado el protagonismo adquirido por el gobierno en las sucesivas prórrogas del Estado de Alarma.

\section{CONCLUSIONES}

En cuanto a las hipótesis planteadas al comienzo de este proyecto y sobre las que se sustenta este trabajo, se puede concluir que:

Se verifica parcialmente la hipótesis número 1 en la que se planteaba que la información acerca de la COVID-19 gana protagonismo y ocupa más espacio en las portadas con el paso de las semanas con necesidad de incluir gráficos e infografías sobre el número de contagiados, víctimas mortales y otros datos estadísticos del impacto de la pandemia. En el análisis se ha observado un crecimiento importante que se hace irrefutable en el paso del mes de febrero a marzo en el que se pasa de un 105 de portadas en las que no aparece nada a un $100 \%$ del total de la portada ocupado por titulares sobre el coronavirus en marzo y abril. 
Sin embargo, aunque los diarios incluyen gráficos e infografías sobre el número de contagiados, víctimas mortales y otros datos estadísticos del impacto de la pandemia a partir del mes de marzo, no se produce por igual en todos los diarios puesto que son El Mundo y La Razón los que incluyen estas infografías tanto en marzo como en abril. En febrero, al centrarse las informaciones en Italia, Europa, la bolsa y los primeros contagiados en España, no se aporta ese tipo de información en ningún diario.

La segunda hipótesis sobre los asuntos abordados queda verificada parcialmente ya que se planteaba que en febrero primaría la información internacional, en marzo la sanitaria y en abril la política y la economía. Si bien en febrero las portadas se centran mayoritariamente en información internacional sobre el virus, en marzo no se aborda principalmente la cuestión sanitaria, sino que también ocupan gran parte del peso informativo de las portadas la política y economía. $Y$ en abril, tal y como se pronosticaba, los asuntos relativos a economía y política son mayoritarios. Por lo tanto, la hipótesis se verifica con los datos recabados en febrero y abril, pero no en marzo donde la política y la economía también ocupan buena parte de la portada.

La tercera hipótesis que planteaba el protagonismo mayoritario de los políticos en las fotografías de portada ha quedado refutado tras el análisis. En los tres meses que comprenden el periodo analizado, el protagonismo de la fotografía, montaje o ilustración principal de la portada en los diarios analizados ha recaído sobre los ciudadanos en mayor porcentaje que en políticos (un 30\% y un 15\% respectivamente de media). Este protagonismo de los ciudadanos se ha repetido, además en los tres periodos de análisis desde febrero hasta abril.

Con esta investigación se ha pretendido mostrar cómo los diarios españoles han optado por mostrar las informaciones sobre la crisis pandémica en su portada, un elemento clave para atraer la atención del lector y revelar cuáles son los temas más relevantes para ellos.

\section{REFERENCIAS}

AIMC (2020). Ranking de diarios. $1^{\underline{a}}$ Ola. Disponible en: http://reporting.aimc.es/index.htm|\#/main/diarios

Andreu-Sánchez, C., \& Martín-Pascual, M. Á. (2020). Fake images of the SARS-CoV-2 coronavirus in the communication of information at the beginning of the first Covid-19 pandemic. El Profesional de la Información, 29(3), e290309. doi: 10.3145/epi.2020.may.09

Berrocal Gonzalo, S. y Rodríguez-Maribona, C. (1998). Análisis básico de la prensa diaria. Manual para aprender a leer periódicos. Madrid: Universitas

Borrat, H. (2003): "Narradores en interacción". I/C. Revista científica de información y comunicación, 1, pp. 59-84. 
La COVID-19 en las portadas de los diarios de difusión nacional en España

Cinelli, M., Quattrociocchi, W., Galeazzi, A., Valensise, C. M., Brugnoli, E., Schmidt, A. L., ... \& Scala, A. (2020). The covid-19 social media infodemic. arXiv preprint arXiv:2003.05004. doi: $\underline{10.1038 / \mathrm{s} 41598-020-73510-5}$

Departamento de Seguridad Nacional (2020). Disponible en http://dsn.gob.es

Dircomfidencial (2020, 28 enero). Los grandes periódicos impresos cierran otro año negro en difusión de ejemplares. Disponible en: https://dircomfidencial.com/medios/continuan-un-ano-mas-las-caidas-de-la-difusionen-papel-de-los-principales-diarios-generalistas-espanoles-20200128-0401/

Francescutti, L. P. (2003). «Vacas locas» y comunicación del riesgo: un análisis de la prensa española. Política y sociedad, 40(3), 153-188. Recuperado de https://revistas.ucm.es/index.php/POSO/article/view/POSO0303330153A/23530

Fusté-Forné, F. (2020). Explicar el virus desde las portadas: un estudio de los periódicos españoles. Revista Española de Comunicación en Salud, 210-217. doi: $\underline{10.20318 / \text { recs.2020.5409 }}$

González, R. B., \& Cambra, U. C. (2015). El virus del ébola: análisis de su comunicación de crisis en España. Opción, 31(4), 67-86. Recuperado de https://www.produccioncientificaluz.org/index.php/opcion/article/view/20539

Grijelmo, A. (2020). "El periodismo en tiempos de coronavirus", en El País. Disponible en

https://elpais.com/elpais/2020/04/24/el pais que hacemos/1587714100 071847.htm !

Informe Quiral (2008). Medicina, Comunicación y Sociedad. Fundació Vila Casas (Universitat Pompeu Fabra). Disponible en https://www.fundaciovilacasas.com/es/informe-quiral/pagina-2

López-Rabadán, P. y Casero-Ripollés, A. (2012). La evolución de la agenda mediática española (1980-2010). Un análisis longitudinal de la portada de la prensa de referencia. Revista Latina de Comunicación Social, 67, 470-493. Disponible en: http://www.revistalatinacs.org/067/art/964 Castellon/20 Casero.html

Maciá-Barber, C. (2020). COVID-19 en portada: radiografía ética de la cobertura fotográfica de la pandemia en España. Revista Española de Comunicación en Salud, 42-58.

McCombs, M. (2006). Estableciendo la agenda. Barcelona: Paidós Comunicación

Martínez Solana, Y. (2004). La crisis de las "vacas locas" en España: la necesidad de una información sanitaria responsable. Estudios Sobre El Mensaje Periodístico, 10, 139 158.

Recuperado

de https://revistas.ucm.es/index.php/ESMP/article/view/ESMP0404110139A 
La COVID-19 en las portadas de los diarios de difusión nacional en España

Masip, Pere; Aran-Ramspott, Sue; Ruiz-Caballero, Carlos; Suau, Jaume; Almenar, Ester; Puertas-Graell, David (2020). "Consumo informativo y cobertura mediática durante el confinamiento por el Covid-19: sobreinformación, sesgo ideológico y sensacionalismo". El profesional de la información, 29(3), e290312. doi: 10.3145/epi.2020.may.1

Monjas-Eleta, M. y Gil-Torres,A. (2019). Comunicación institucional y tratamiento periodístico de la crisis del ébola en España entre el 6 y el 8 de octubre de 2014 . Revista de Comunicación, 16(1), 97-121. https://revistadecomunicacion.com/article/view/1009

Palau Sampio, D. (2013). La actualidad decantada. Enfoques y estilos en los titulares de portada. Estudios sobre el Mensaje Periodístico, 19(9), 825-839. doi: 10.5209/rev ESMP.2013.v19.n2.43474

Pérez-Dasilva, Jesús-Ángel; Meso-Ayerdi, Koldobika; Mendiguren-Galdospín, Terese (2020). "Fake news y coronavirus: detección de los principales actores y tendencias a través del análisis de las conversaciones en Twitter". El profesional de la información, 29(3), e290308. doi: 10.3145/epi.2020.may.08

(2007). Medios de comunicación y crisis informativa: a propósito del 11M. En: Esteve, F. Y. Moncholi, M. A. Teoría y técnicas del periodismo especializado. Editorial Fragua: Madrid, pp. 71-82.

Revuelta, G., \& De Semir, V. (2008). Informe Quiral 10 años: medicina y salud en la prensa diaria. Barcelona: Universitat Pompeu Fabra.

Villafranca, P. L. (2012). Los encuadres sanitarios en prensa española: El caso de la gripe A y la bacteria E. Coli. Revista Internacional de Relaciones Públicas, 2(4), 221246. doi: $\underline{10.5783 / R I R P-4-2012-10-221-246 ~}$

\section{AUTORES}

\section{María Monjas Eleta}

Profesora del Grado en Periodismo y del Máster en Investigación de la Comunicación como agente histórico y social de la Universidad de Valladolid, Doctora por la Universidad de Valladolid (2012), Máster de Radio de la Universidad Complutense de Madrid y Radio Nacional de España (1998) y Licenciada en Ciencias de la Información por la Universidad Pontificia de Salamanca (1996). Su investigación se centra en estudio del mensaje periodístico, concretamente el periodismo especializado en ciencia y cultura, los nuevos medios y la enseñanza del periodismo. Miembro del Grupo de Investigación en Nuevas Tendencias de Comunicación (NUTECO).

Orcid ID: http://orcid.org/0000-0003-0626-7761

Google Scholar: https://scholar.google.es/citations?user=0EtLY3EAAAAJ\&hl=es 
La COVID-19 en las portadas de los diarios de difusión nacional en España

\begin{abstract}
Alejandro Rodríguez Holguín
Grado en Periodismo por la Universidad de Valladolid. Beca Agencia Efe.

Orcid ID: https://orcid.org/0000-0002-0991-6336
\end{abstract}

\begin{abstract}
Alicia Gil-Torres
Doctora en Periodismo (Premio Extraordinario), Master en Consultoría Política, Licenciada en Publicidad y Relaciones Públicas y Graduada en Periodismo. Profesora Ayudante Doctor en la Universidad de Valladolid en el Grado de Periodismo. Miembro del proyecto de investigación "Politainment en el entorno de la posverdad: nuevas narrativas, clickbait y gamificación» y del GIR Nuteco. Las líneas de investigación son comunicación política, campañas electorales y comunicación.

Orcid ID: http://orcid.org/0000-0002-8042-2208

Google Scholar: https://scholar.google.es/citations?user=sYmJrS4AAAAJ\&hl=es

Research Gate: https://www.researchgate.net/profile/Alicia Gil-Torres

Scopus ID: https://www.scopus.com/authid/detail.uri?authorld=57195761187

Academia.edu: https://uva-es.academia.edu/AGilTorres
\end{abstract}

